\title{
A NEW SPOTTED CHILOSCHISTA (ORCHIDACEAE: AERIDINAE) FROM BHUTAN
}

\author{
Choki Gyeltshen $^{1}$, Stig Dalström ${ }^{2.5}$, Nima Gyeltshen ${ }^{3} \&$ Kezang Tobgay ${ }^{4}$ \\ ${ }^{1}$ Senior Biodiversity Officer, National Biodiversity Centre, Ministry of Agriculture and Forests, \\ Serbithang, Thimphu, Royal Government of Bhutan \\ 22304 Ringling Boulevard, unit 119, Sarasota FL 34237, USA; Lankester Botanical Garden, \\ University of Costa Rica, Cartago, Costa Rica; National Biodiversity Centre, Serbithang, \\ Royal Government of Bhutan \\ ${ }^{3}$ Biodiversity Supervisor, Royal Botanic Garden, National Biodiversity Centre, \\ Ministry of Agriculture and Forests, Serbithang, Thimphu, Royal Government of Bhutan \\ ${ }^{4}$ Biodiversity Officer, Royal Botanic Garden, National Biodiversity Centre, Serbithang, Thimphu, \\ Royal Government of Bhutan \\ ${ }^{5}$ Corresponding author: stigdalstrom@gmail.com
}

\begin{abstract}
A new species of Chiloschista from a restricted area in Bhutan is described and illustrated. It is compared with C. parishii from Myanmar and Thailand, which has similarly colored flowers and from which it differs by the larger flowers, $15-18 \mathrm{~mm}$ versus $8-10 \mathrm{~mm}$, and the lack of a glandular and pubescent, erect and curved callus lobe inside the lip, which is generally seen in other similarly colored species of this genus.
\end{abstract}

Key Words: Aeridinae, Bhutan, Himalaya, new Chiloschista, Orchidaceae, Vandeae

Introduction. During an orchid inventory in the southern part of Bhutan in May 2014 by a research team from the National Biodiversity Centre in Serbithang, Bhutan (NBC), plants of a Chiloschista Lindl., species without flowers were found growing as epiphytes on small trees in deep shade near the Gelephu Tshachu, or hot springs, just north of the city of Gelephu in the Sarpang District near the Indian border (Fig. 1-2). A few plants were collected for cultivation at the Royal Botanic Garden in Serbithang where one plant flowered in May the following year (Fig. 3-4). The identity of this plant turned out to be unknown and after some research it was concluded that it represented a new species. The flowers are yellow with brown spots like many other members of this genus but the internal structure of the lip is distinct from other similarlooking species. Based on what appears primarily to be the color pattern of the sepals and petals, several other species have been incorrectly treated mainly as Chiloschista lunifera (Rchb.f.) J.J.Sm, or as Chiloschista parishii Seidenf., (Fig. 5-6) in the past. In an attempt to avoid adding further confusion to the rather complex history of these and similar species at this time, we refer here to Gunnar
Seidenfaden's discussion about this subject and his description of C. parishii (Seidenfaden 1988). For readers who do not have access to this publication we summarize some of Seidenfaden's reasoning here: "The file folder with Thrixspermum luniferum in Herb. Reichenbach [today inserted in the general herbarium at the Museum of Natural History in Vienna, Austria] contains a mixture of two species. The type is represented by a sheet (41550b) with some inflorescences sent by Veitch; this is supplemented by coloured sketches (41549, left hand), accompanied by the handwritten diagnosis. The other material consists of a flowerless plant of Parish, no. 55 (26237) from Moulmein, accompanied by Parish's coloured drawing (11583); this is the one Reichenbach published as Thrixspermum luniferum in 1874 [Reichenbach did not refer to Parish 55 specifically but listed Thrixspermum luniferum, described by him in 1868 and sent to him by Veitch, as having been collected by Parish simply by including this species in the 1874 publication, which was dedicated to Parish's collections in the Moulmein area of Myanmar]. There is a flowering plant received from Low, collected by Boxall in 1879 (41550a), this is sketched in colour (41549, 


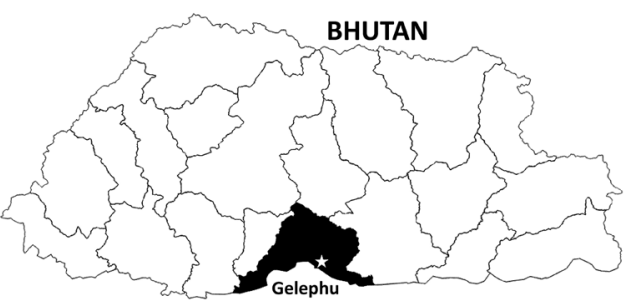

Figure 1. Map of Bhutan indicating the place of the type collection of Chiloschista gelephuense near the Gelephu Tshachu hot springs.

right hand). All this material is not Chiloschista lunifera, see C. parishii below. When Hooker f. in 1890 recorded Sarcochilus luniferus he had no access to Reichenbach's herbarium [which was locked up for 25 years since 1889]. But he had a specimen of Parish no. 55 and was misled by Reichenbach's publication of 1874. Most later authors are equally wrong when they record a 'lunifera'." (Seidenfaden 1988).

Seidenfaden (1988) continues with describing Chiloschista parishii based on Parish's collection
\#55 and adds: "This is the plant fully described by earlier authors under the name Sarcochilus luniferus or Chiloschista lunifera. As earlier explained, Reichenbach in 1874 made a mistake in referring a Parish plant to Thrixspermum luniferum, and with the closing of his herbarium that plant was the only one available to Hooker f."

We realize that the name "Chiloschista parishii" is frequently used in various publications for species that share the coloration of the flowers (yellow with brown spots) but differ in other characteristics and in reality represent different species (Pearce \& Cribb 2002, Gurung 2006, Raskoti 2009) some of which remain to be scientifically described and named. It is not the present authors' ambition to deal with that subject in this current paper, but we will focus on some of these other species in future articles when more material is available. The original collection of what became Chiloschista parishii was made by Reverend Charles Samuel Pollock Parish (\#55), presumably in the "Moulmein" area of Myanmar. For some reason unknown to us, his name's initials are listed as "E.

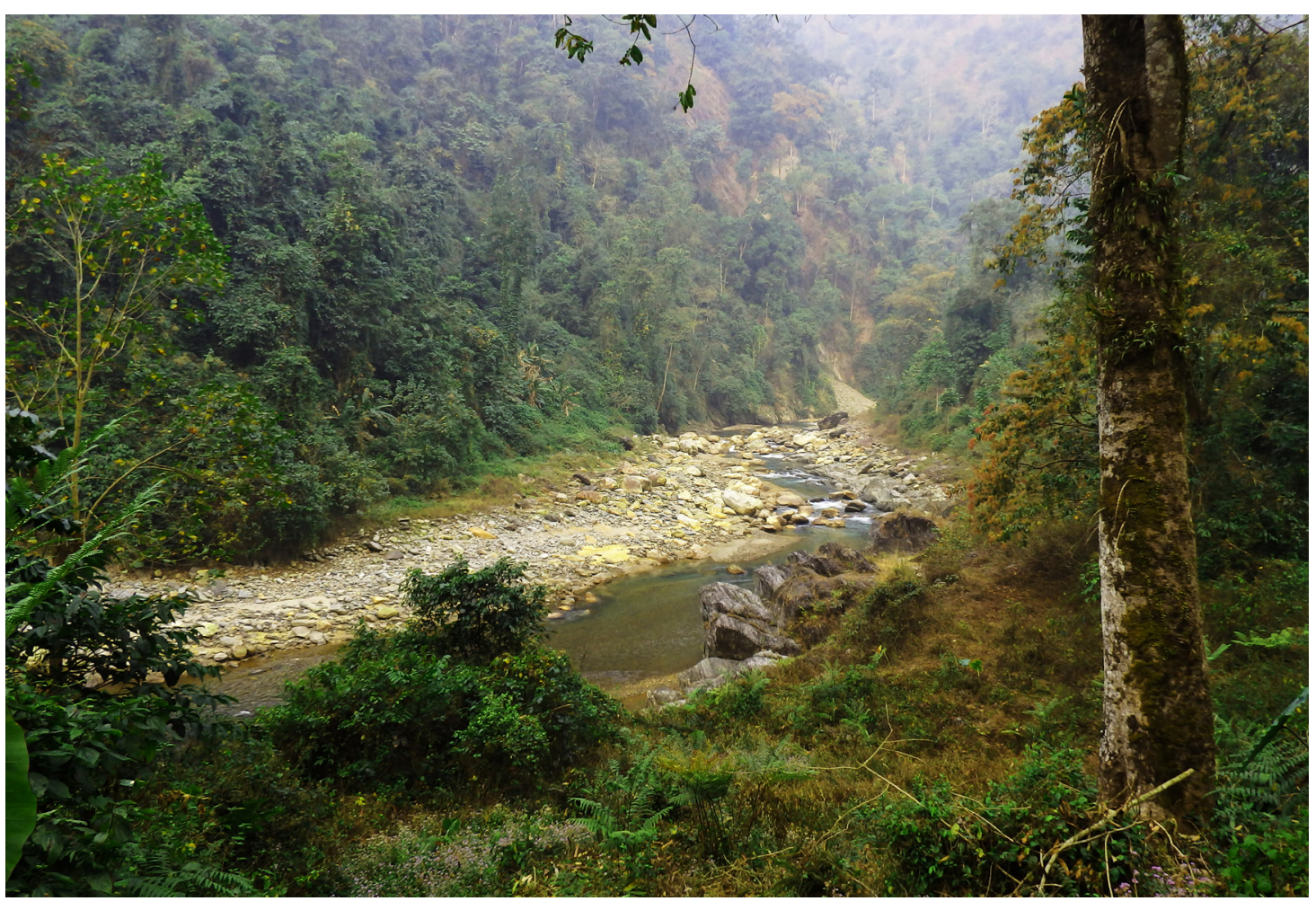

FIGURE 2. Chiloschista gelephuense grows as an epiphyte along the Mo Chu River, north of the city of Gelephu. 
C." rather than C. S. P. Parish in the Transactions of the Linnean Society publication (Reichenbach 1874). In any case, a drawing of this plant exists in the herbarium of the Museum of Natural History in Vienna, and is dated May 14, 1869 (W11583). Gunnar Seidenfaden honored Parish by naming this species after him and basing his description on the flower-less specimen in Vienna (W26237) and the colored drawing by Parish (W11583) as the holotype. Chiloschista parishii is illustrated in Seidenfaden's treatment (1988) based on a collection from Doi Saket in Thailand ("GT 7403, C!"; Seidenfaden 1988). Plants that were later identified as Chiloschista parishii (Fig. 6) were observed by author Dalström and others at a local market near the border between Thailand and Myanmar 2009. These plants were collected in Myanmar according to the people who were selling them.

\section{TAXONOMIC TREATMENT}

Chiloschista gelephuense Ch.Gyeltshen \& Dalström, sp. nov.

TYPE: Bhutan. Gelephu: North of Gelephu Tshachu hot springs along road to the abandoned limestone quarry, N2656'50"; E90³0'41", alt. ca. $300 \mathrm{~m}$, epiphytic in shade on smaller trees, collected on 12 May, 2014, and flowered in cultivation at the Royal Botanic Garden, Serbithang, 12 May, 2015, S. Dalström 4212 \& Ch. Gyeltshen (holotype: THIM) (Fig. 3-4).

Diagnosis: Chiloschista gelephuense is superficially similar to $C$. parishi in the yellowish flowers with brown spots on the sepals and petals, but differs by the larger flower, $15-18 \mathrm{~mm}$ across versus $8-10 \mathrm{~mm}$ across for the latter species. Chiloschista gelephuense also differs from other similarly colored species in the genus by the lack of a glandular pubescent, erect and curved callus lobe inside the lip.

Epiphytic herb. Roots numerous, spreading, terete to slightly flattened, 2-3 mm in diameter. Stem reduced, virtually absent. Leaves seasonal in the wild during the rainy period, not seen on the type. Inflorescence sub-erect to pendent, $15-16 \mathrm{~cm}$ long, almost straight to indistinctly flexuous, micro-pubescent, laxly

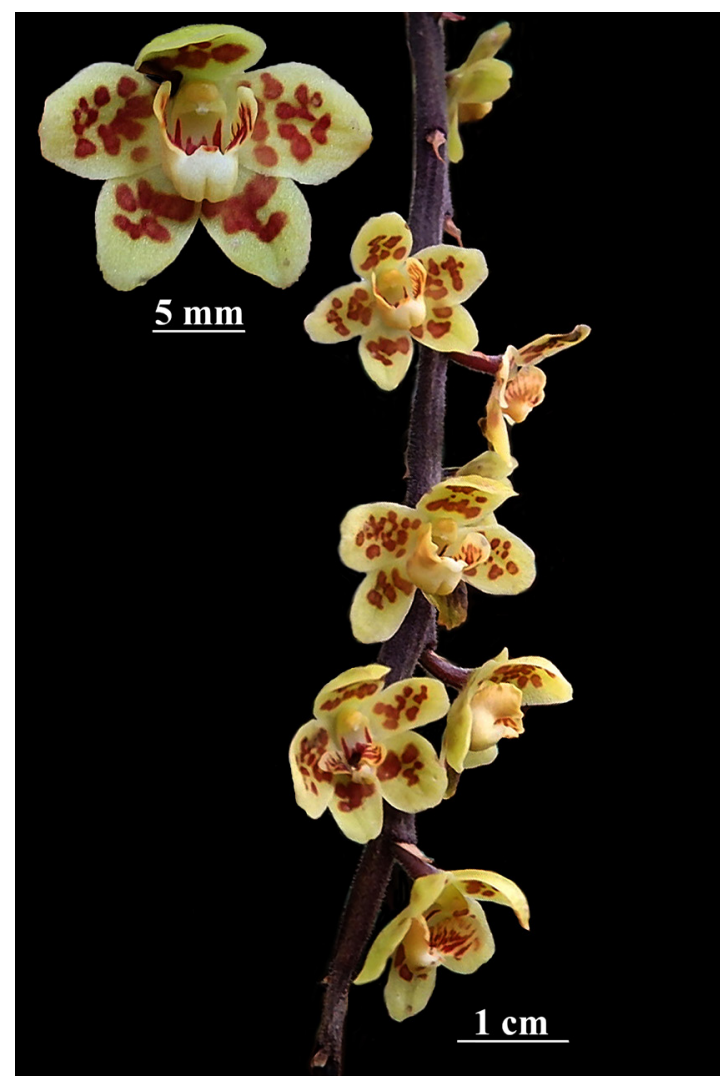

FIGURE 3. Chiloschista gelephuense flowered in cultivation at the Royal Botanic Garden, Serbithang, in May of 2015.

many-flowered; peduncle $c a .5 \mathrm{~cm}$ long; rachis $c a$. $10.5 \mathrm{~cm}$ long; bracts scale-like, narrowly acute, 3-4 mm long. Pedicel with ovary micro-pubescent, 5-6 mm long. Flower with rather flat and spreading lateral sepals and petals and with the dorsal slightly bent forward over the column, 15-18 mm across; dorsal sepal light yellow with distinct reddish brown spots, externally basally micro-pubescent, apically and internally glabrous, broadly elliptic, apically indistinctly obtuse to rounded, 9-10 × 6.5-7.0 mm; lateral sepals similar in color and pubescence, fused basally along the column foot, indistinctly obliquely obovate to broadly elliptic, apically rounded, 7.5$8.0 \times 5.5-6.2 \mathrm{~mm}$; petals similar in color, glabrous, sessile and fused to the column foot, subrectangular to indistinctly obovate, apically rounded, 8.0-8.5 $\times 5.0-5.5 \mathrm{~mm}$; lip externally whitish with a small irregular brown marking at the tip of the front-lobe, internally with dark red-brown stripes and markings, 


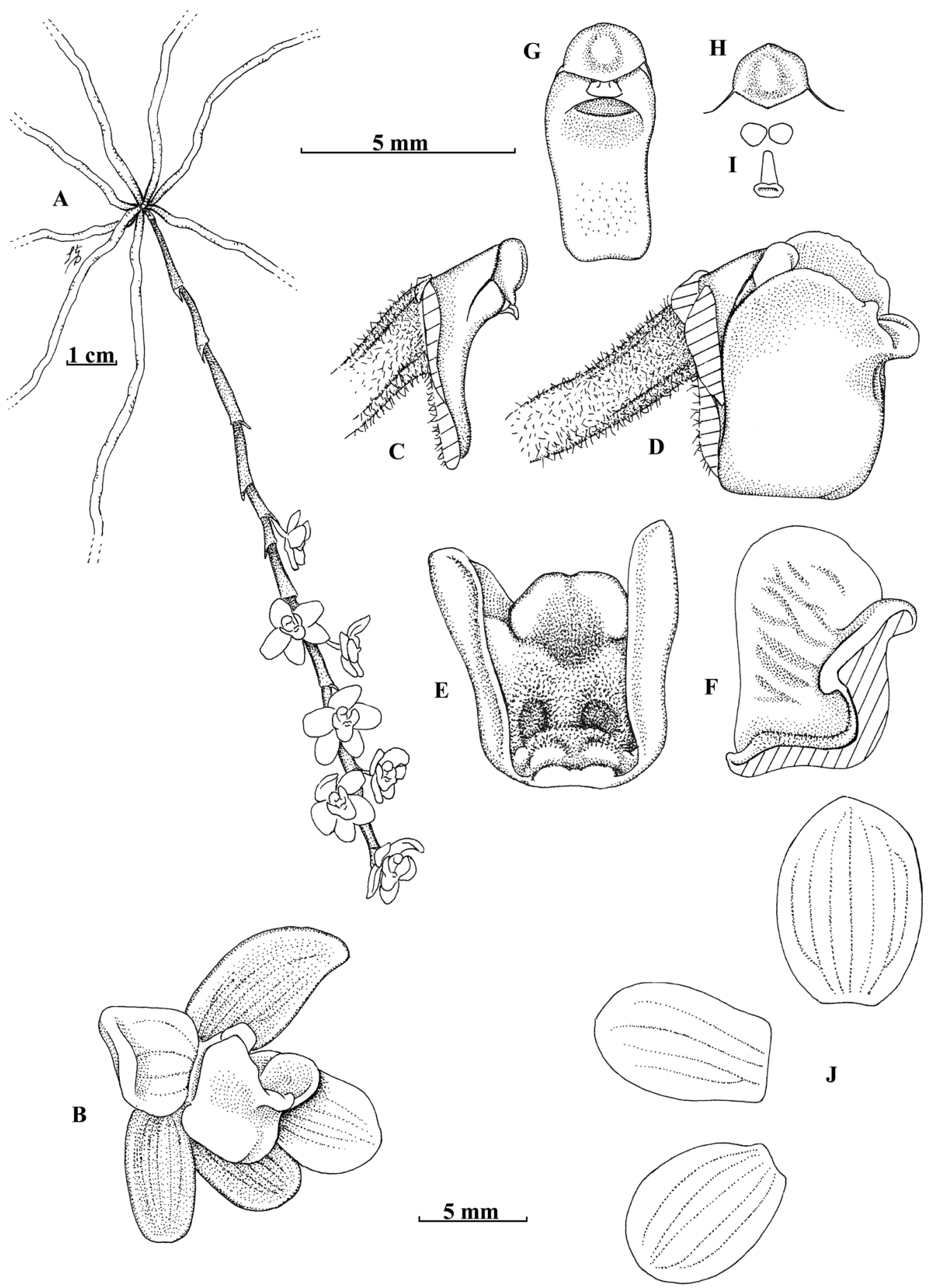

Figure 4. Chiloschista gelephuense Ch.Gyeltshen \& Dalström. A. Plant habit. B. Flower in front angled view. C. Column lateral view. D. Column and lip lateral view. E. Lip back (internal) view. F. Lip cleft, lateral view. G. Column ventral view. H. Anther cap dorsal view. I. Pollinarium back view. J. Dissected flower. Drawn from the holotype by Stig Dalström. 

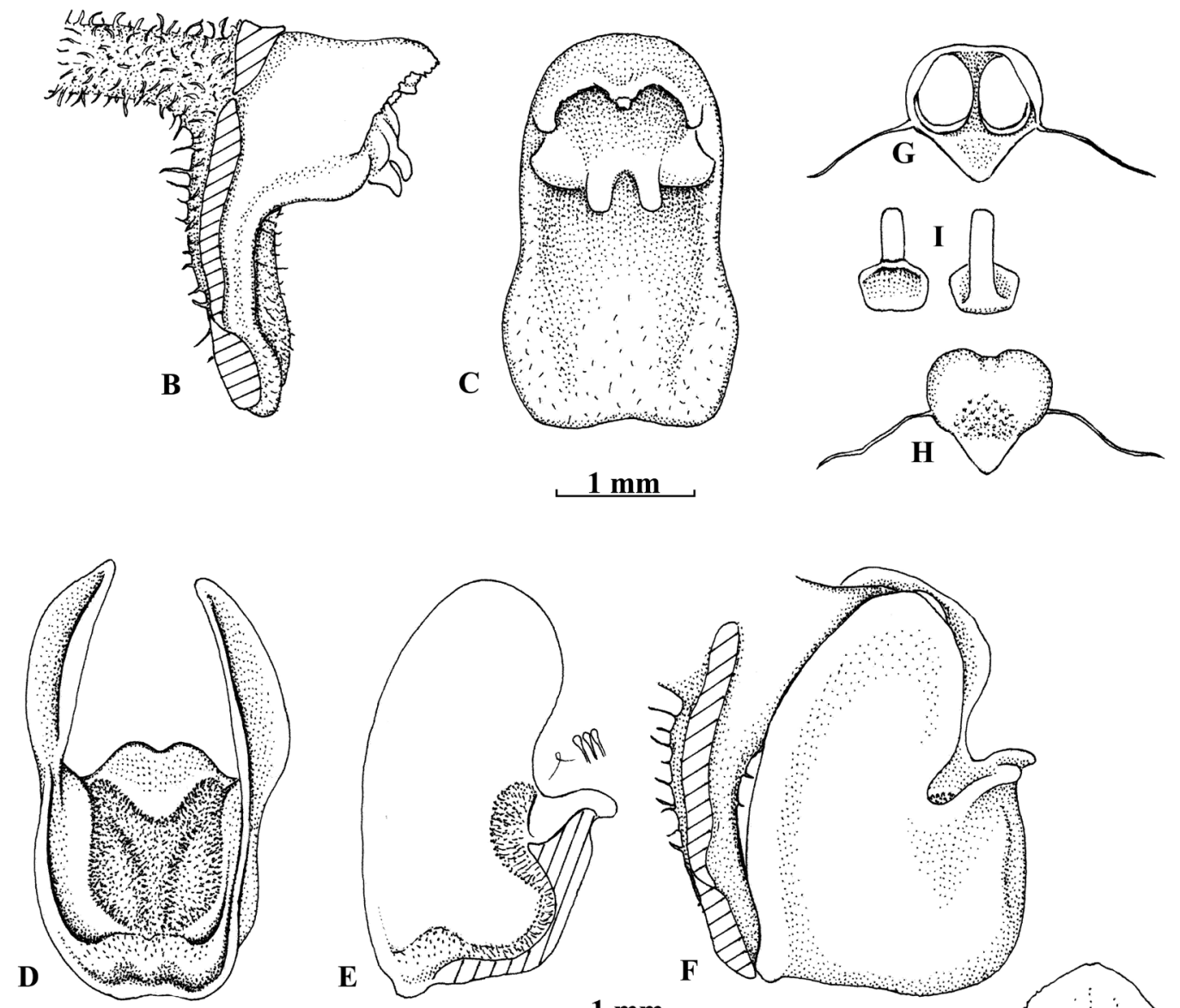

$\mathbf{E}$
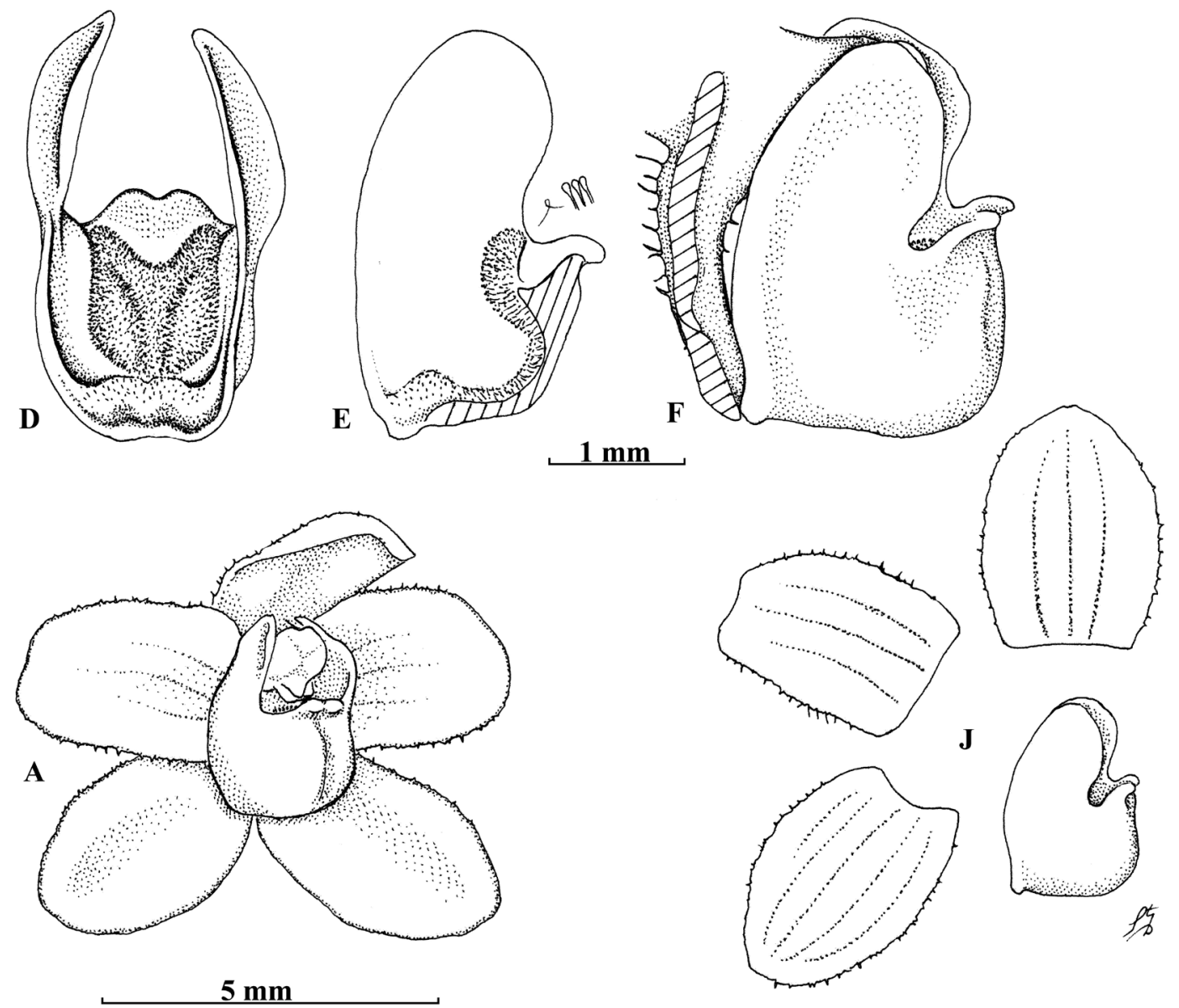

Figure 5. Chiloschista parishii Seidenfaden. A. Flower front angled view. B. column lateral view. C. Column ventral view. D. Lip back (internal) view. E. Lip cleft, lateral view. F. Column and lip lateral view. G. Anther cap with pollinia ventral view. H. Anther cap dorsal view. I. Stipe and viscidium back and front view. J. Dissected flower. Drawn from S. Dalström 3023 (Dalström archives) by Stig Dalström. 


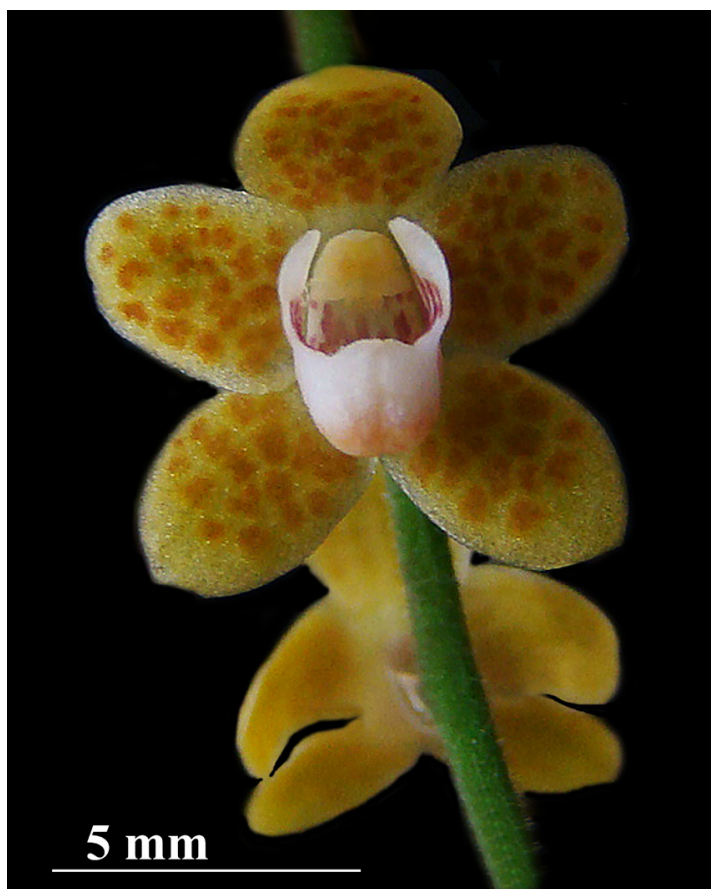

FIGURE 6. Chiloschista parishii from Myanmar, sold at a local border market in western Thailand. rigidly attached to the column foot, deeply saccate and slightly canaliculated ventrally, tri-lobed, lateral lobes erect to indistinctly curved inwards, apically rounded, front-lobe short, fleshy, indistinctly bi-lobed and labiate, slightly recurved, $6.0-6.5 \mathrm{~mm}$ high and $5.5-5.8 \mathrm{~mm}$ wide; callus a fleshy, broad and micropubescent swelling, from the base up to the base of the front-lobe, with a pair of low more or less ovoid, glandular pubescent swellings on each side, apically divided into a pair of fleshy knobs, with some glandular micro-pubescence in between; column very short and stocky, $c a$. 1.5-2.0 mm long, excluding the anther cap and the column foot, 2.0-2.2 mm long; anther cap light yellow, galeate with a pair of hairlike, $c a .1 \mathrm{~mm}$ long tendrils on each side; pollinarium of 2 obliquely globose and indistinctly flattened, cleft pollinia on a narrowly rectangulate triangular stipe, $c a .1 \mathrm{~mm}$ long on a sub-quadrate, indistinctly concave viscidium.

Distribution: Chiloschista gelephuense is currently only known from the original type area near the Tshachu hot springs north of the city of Gelephu in

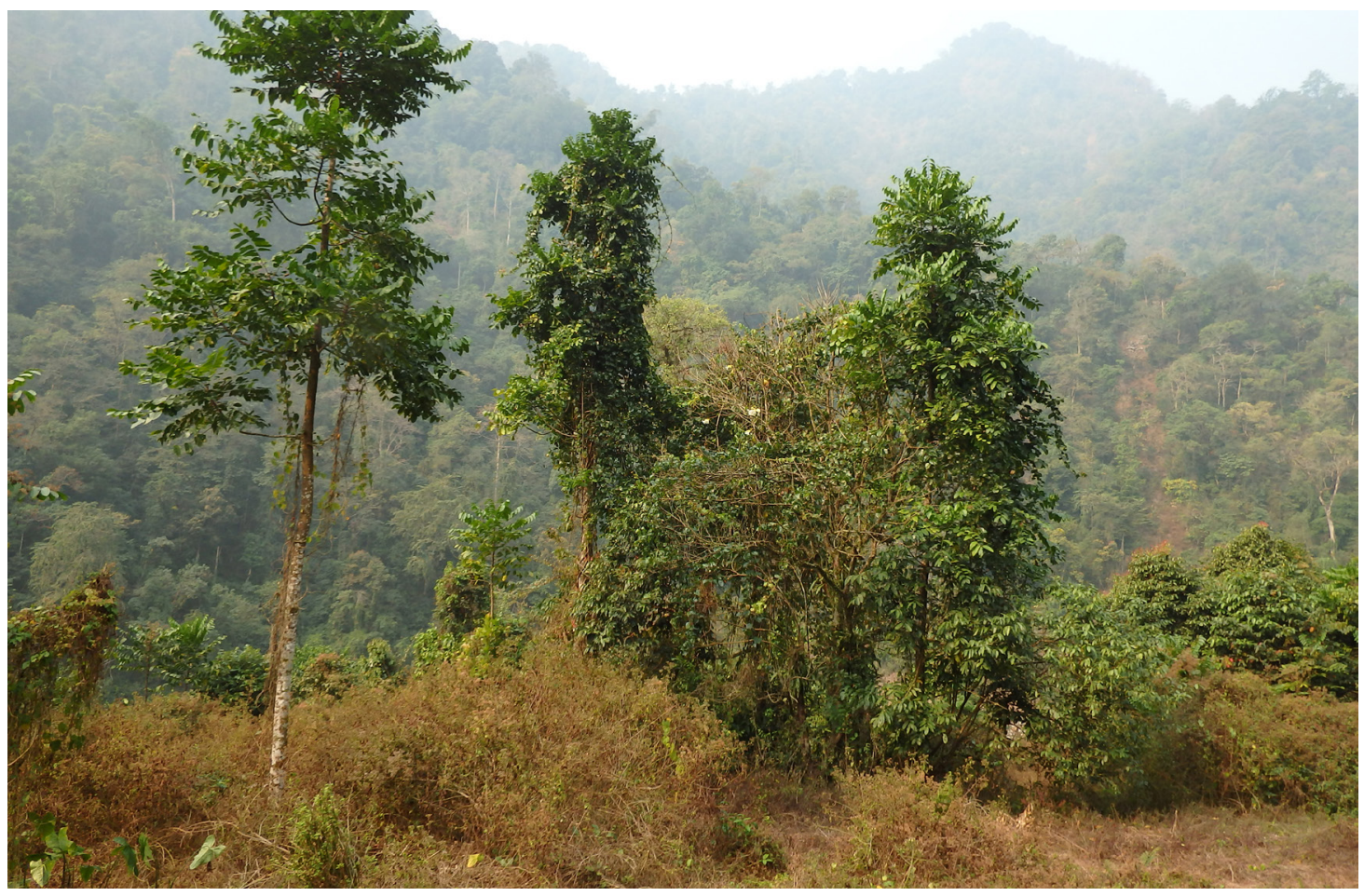

FIGURE 7. Natural habitat of Chiloschista gelephuense, growing epiphytically on Beaumontia grandiflora (the messy looking vine in the center), and on Aphanamixis polystachya to the right in this little cluster of trees. 
southern Bhutan. No additional flowering specimens of Chiloschista gelephuense has been observed, only plants in bud growing epiphytically on Beaumontia grandiflora Wall., (Apocynaceae) and Aphanamixis polystachya (Wall.) Parker (Meliaceae) close to the type locality (Fig. 7-8).

Etymology: Named in reference to the sub-district (Dungkhag) of Gelephu, currently the only area where this species has been found.

ACKNOWLEDGMENTS. The authors would like to thank Tashi Y. Dorji, Program Director of the NBC, for her guidance and support. We also thank Sangay Dema (NBC), and Dupchu Wangdi (NBC) and Thomas Höijer for excellent companionship in the field. We sincerely thank the Sarasota Orchid Society for continuous financial support and Wesley Higgins and the anonymous reviewers for improving the manuscript. Finally we thank Sharon and Russell Stephens of Sarasota, Florida, for contributing travel funds for the second author through grant \#20181806 from the Friends of Orchid Research Fund, administrated by the Community Foundation of Sarasota County.

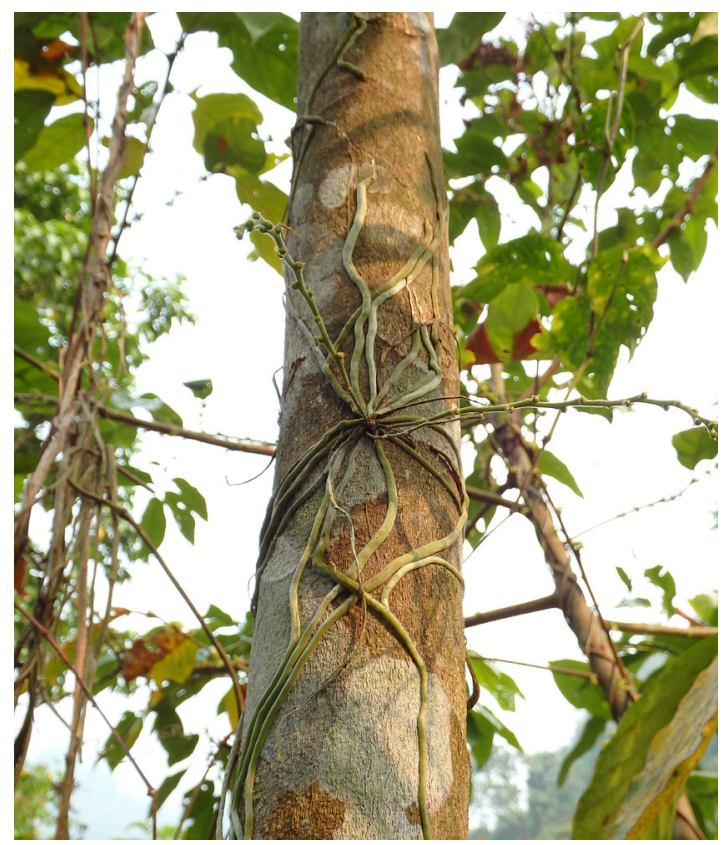

Figure 8. A plant of what is believed to be Chiloschista gelephuense, growing on the trunk of Aphanamixis polystachya near the type area.

\section{LITERATURE CITED}

Gurung, D. B. (2006). An illustrated guide to the orchids of Bhutan. Thimphu, Bhutan: DSB Publication.

Pearce, N. R. \& Cribb, P. J. (2002). The orchids of Bhutan. Royal Government of Bhutan: Royal Botanic Garden of Edinburgh.

Raskoti, B. B. (2009). The orchids of Nepal. Kathmandu, Nepal: Published by Bhakta Bahadur Raskoti and Rita Ale.

Reichenbach, H. G. (1874). Enumeration of the orchids collected by the Rev. E. C. Parish in the neighbourhood of Moulmein. The transactions of the Linnean society of London, 30(1), 133-156.

Seidenfaden, G. (1988). Chiloschista Lindl. Orchid genera in Thailand 14. Fifty-nine vandoid Genera. Opera Botanica, 95, 168-181. 
LANKESTERIANA 